\title{
Non-formal science education: The relevance of science camps
}

\author{
Julia Halonen and Maija Aksela \\ The Unit of Chemistry Teacher Education, Department of Chemistry, \\ Faculty of Science, University of Helsinki, Finland
}

\begin{abstract}
Non-formal science education means goal-oriented learning outside of school. The use of out of school learning environments (e.g. science camps) has been found to increase motivation and interest in natural sciences. In this study, the relevance of non-formal science education in science camps has been analyzed from the perspectives of children and families, which has not been studied before. The analysis of relevance has been based on the relevance theory developed by Stuckey, Hofstein, Mamlok-Naaman \& Eilks in 2013. The study focuses on the 46 science camps organized by the University of Helsinki LUMA Centre in the years 2015 and 2016, involving more than 900 schoolchildren and some of their parents $(\mathrm{N}=124)$. The study examined also the impact of children's gender and children's earlier interest in science on the relevance of chemistry related science camps. Survey and theme interview were both used as research methods.
\end{abstract}

The results of the survey show that non-formal science education in science camps is relevant according to both the children and the families, mainly at the level of individual relevance, with emphasis on present and intrinsic dimensions of relevance. The tasks related to the camp themes, for example in chemistry camps, experimental work in the laboratory, and friends made in the science camps are the most relevant for children. The chemistry science camps are individually most relevant to those children who didn't have much earlier interest in chemistry. Boys are more confident about their own interests at the individual relevance level than girls. At the level of societal relevance, boys are more focused on present-day relevance than girls when girls also consider the future. The levels of societal and vocational relevance were only slightly visible in the answers of the survey. However, based on theme interviews, camps were considered as relevant for all relevance levels of the relevance theory.

The results of this research can be utilized in the development of out of school learning environments, especially in the development of science camps and in further research.

Keywords: non-formal education, out of school learning, relevance, science camp

Contact: julia.halonen@helsinki.fi

DOI: https:/ / doi.org/ 10.31129/ LUMAT.6.2.316 
One of the most important tasks of science education is to support the student's personal interest. An interest in the subject will substantially affect how the student works or what choices he or she does in his or her life. (Krapp \& Prenzel, 2011) The importance of non-formal science education has increased in recent years and, as a result, the supply of various non-formal learning opportunities has also been significantly expanded. (Affeldt, Tolppanen, Aksela \& Eilks, 2017). Non-formal science education includes, among others, various science clubs and camps, science labs and laboratories operating at universities and all kinds of science fairs.

Many studies show that studying natural sciences - especially chemistry, physics and engineering - is not popular among students. (e.g. Osborne, Simon \& Collins, 2003; Dillon, 2009; Hofstein, Eilks \& Bybee, 2011; Stuckey, Hofstein, MamlokNaaman \& Eilks, 2013). Pupils are not interested in studying chemistry, and one of the frequent reasons for this is that chemistry learning is not considered relevant for their everyday life or even for society. The modification of teaching to be more relevant was already at 1980's (Newton, 1988) considered to be the way to motivate students and to make them more interested in learning science. (Eilks \& Hofstein, 2015)

Despite the fact that more relevant teaching is continuously offered as a solution to weaker learning outcomes, the relevance of teaching has been studied very little compared to, for example, motivation and interest research. To enable the most relevant teaching, research data on what relevant teaching really is and which factors make the lesson relevant, is needed. The model published in 2013 by Stuckey et al. provides a means of studying the relevance of teaching, and this model has also been used in this study. According to the model, relevant teaching is not just about increasing interest, because taking into consideration the pupil's interests increases the relevance of teaching only on a personal level. According to Stuckey et al. (2013), teaching should be relevant both at the individual, societal, and vocational level. Relevant learning also includes both intrinsic and extrinsic dimensions, as well as present and future relevance.

Non-formal teaching has been discovered to increase the motivation of pupils and improving their attitudes towards natural sciences (Jarvis \& Pell, 2005, Orion \& Hofstein, 1991, Nadelson \& J ordan, 2012). Consequently, non-formal learning environments can be seen as a solution to the decreasing interest in learning science. However, non-formal education has been studied quite little compared to formal 
school education, so new information on the subject is needed so that, for example, the teaching in science camps can be developed as closely as possible to meet the needs.

Recent research shows that non-formal learning environments, especially participation in science camps, has increased the children's motivation and interest in natural sciences (e.g. Davis \&Hardin, 2013; Hayden, Ouyang, Scinski, Olszewski \& Bielefedlt, 2011). Research has shown that science camps also enable more profound and detailed themes than formal school education, or shorter workshops, such as clubs (Nugent et al., 2010). Participation in science camps is claimed to increase the interest and motivation of children to consider the future career in the natural sciences. (Mohr-Schroeder et al., 2014).

The aim of this study is to look at the relevance of non-formal science education in science camps from the point of view of children attending the LUMA Centre camps at the University of Helsinki. Along with the children's perspective, the perspective of families is studied. The paper examines also whether children' and families' views about relevance in science camps agree with each other.

\section{Theoretical framework}

The theoretical framework in this study includes the theory of non-formal science education and previous research data as well as the relevance theory through which non-formal science education in science camps was studied in this study.

\subsection{Non-formal education}

Non-formal science education has been defined by many different actors, but with the same principles. Singh (UNESCO GUIDELINES, 2012) defines non-formal learning as follows: Non-formal learning is learning that is carried out in addition to or instead of formal learning. In some cases, non-formal learning can be structured, but it is always more flexible than formal learning. Non-formal education is often organized by various social organizations and takes place in communal spaces.

According to Werquin (2007), non-formal learning means goal-oriented learning, but without formal learning goals. In practice, this means that the learning objectives for non-formal learning are the responsibility of the party providing the teaching, and the objectives are not defined, for example, in national curricula. Non-formal learning 
can, based on the definition of Werquin (2007), happen at workplaces, museums, science centers, and various science circles or academic libraries. Eshach (2007), in turn, draws the distinction between non-formal and formal teaching that, although non-formal learning can be tied to formal school activities, the environment is always less formal than in the normal school teaching. According to Eshach (2007), nonformal learning is generally not evaluated, and learning goals are not defined according to any formal plan.

\subsection{Relevance in science education}

When discussing the relevance of teaching, the term Relevance is used to describe the student's interest (Childs, 2006, Ramsden, 1998) and how meaningful everyday life phenomena appear to individuals and society. An example of this is the application of science and technology through sustainable development to socio-economic, environmental and political issues (De Haan, 2006; Hofstein \& Kesner, 2006). Relevance also explains how well the pupils perceive the usefulness of using everyday contexts in teaching (Gilbert, 2006; King, 2012; Lyons, 2006; Mandler, MamlokNaaman, Blonder, Yayon, \& Hofstein, 2012) and it has been used as a synonym for importance, usefulness and needs (Keller, 1983; Simon \&Amos, 2011).

Stuckey et al. (2013) created a coherent model for the concept of relevance. According to this model, the relevance of education should be evaluated on three different levels: individual, societal, and vocational relevance. The validity of this classification is supported by the fact that Van Aalsvoort has already described the concept of relevance in a similar way in 2004. In addition to the above mentioned three levels, Stuckey et al. (2013) model takes into account the intrinsic and extrinsic relevance of teaching and whether learning is relevant to the pupil's life right now or in the future.

Stuckey et al. present a model diagram for evaluating the relevance of science teaching. This model diagram can be utilized for example in the designing of teaching. The principle of the model has been simplified in Figure 1 below. 


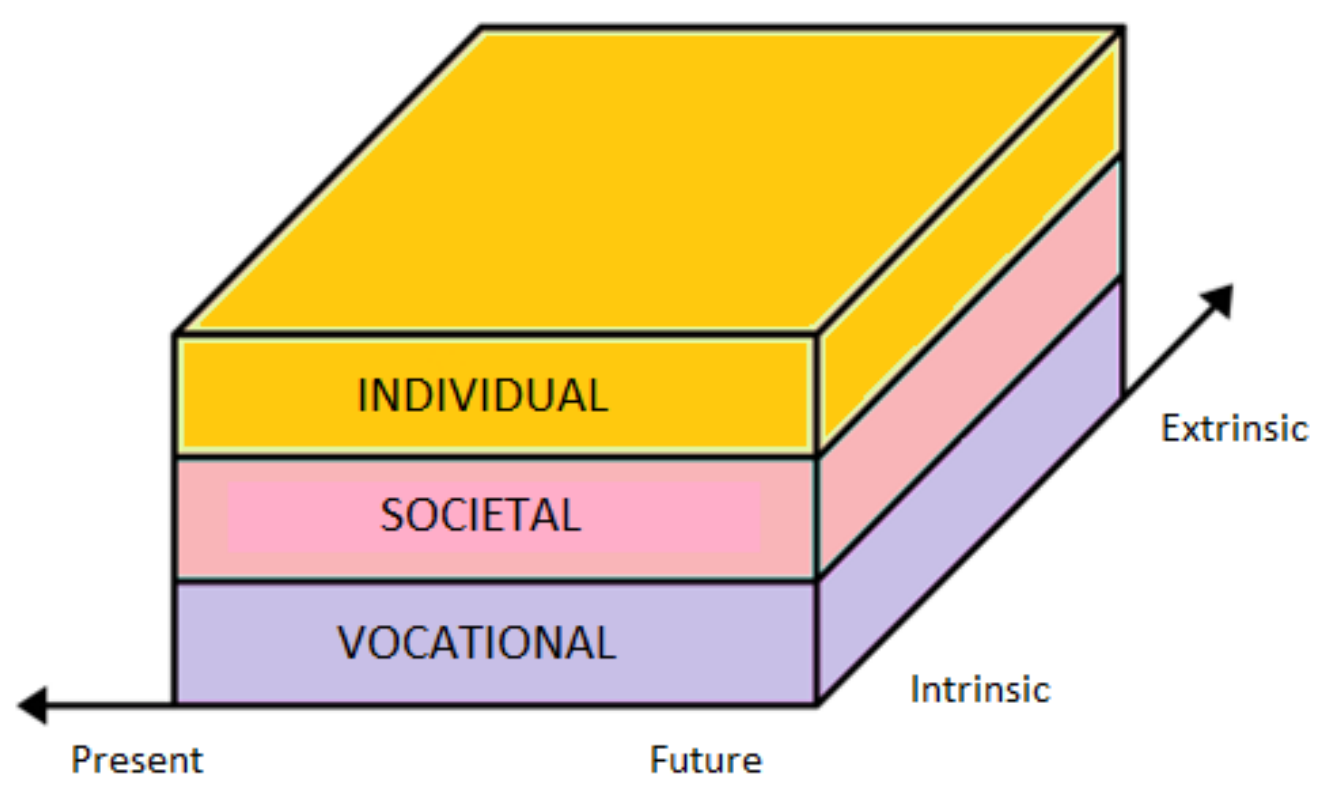

Figure 1. Levels and dimensions of relevant education

According to the model presented above, the effects of the most relevant science education on the learner can be diverse and yet equally relevant. The article (Stuckey et al., 2013) briefly states that science education becomes relevant for education, when learning has positive effects on the learner's life. Relevance should be a concept used by curriculum designers and teachers so that they can assess the relevance of their own hourly plans. (Newton, 1988) The model is designed specifically for the purpose of allowing teachers to actively analyze their hourly plans and possibly modify them so that teaching is as relevant to the learner as possible. (Stuckey et al., 2013)

Stuckey et al. (2013) have used the model in teacher training. It has been used, among others, as a tool for reflection of the relevant science education objectives and as a tool for evaluating different teaching methods. The model has also been utilized in research in science education, for example in science competitions and MOOC (Massive Open Online Course) - related research (Mutanen, 2015; Aksela, Wu \& Halonen, 2016). Earlier studies have shown that the level of individual relevance is emphasized in student responses compared to societal and vocational levels.

\subsection{Science camps as a non-formal learning environment}

Science camps have been organized for many years around the world with the aim of providing children and young people with non-formal activities where they are free to access natural sciences, technology and mathematics. Science camps also aim to 
introduce children and young people to LUMA-experts in an authentic working environment. The purpose of this activity has been to show career opportunities and the hope that children and young people would be more likely to consider a career in natural sciences. (Mohr-Schroeder, J ackson, Miller, Walcott, Little, Speler, Schooler \& Schroeder, 2014)

Although the relevance of science education in a science camp environment has not been studied very much, the pupils' interest and motivation towards natural sciences has been studied. Recent studies show that participation in science camps has increased the children's motivation and interest in the natural sciences and possibly also the interest towards a career in natural sciences (e.g. Davis \& Hardin, 2013; Hayden, Ouyang, Scinski, Olszewski \& Bielefedlt, 2011; Nugent, Barker, Grandgenett, And Adamchuk, 2010). Science camps also allow more profound and more detailed themes than formal school education or shorter workshops such as clubs (Nugent et al., 2010). It is alleged that participation in science camps and nonformal activities in general is raising the interest of children and motivating them towards natural career options (Mohr-Schroeder et al., 2014).

\subsection{Research questions}

Which levels of relevance are emphasized in science camps according to the children?

a. Does previous interest in natural sciences affect the relevance of science camps?

b. Does gender affect the relevance of science camps?

Which levels of relevance are emphasized in science camps according to the families of the children attending the science camp?

a. Do the families have a similar opinion about the relevance in science camps than the children? 


\section{Research methodology}

During this study, in the years 2015 and 2016, the University of Helsinki LUMA Centre organized a total of $46(23+23)$ science camps during the summer holiday season under different mathematical and scientific themes. More than 900 primary school children and some of their guardians $(\mathrm{N}=124)$ participated in this study. The camps lasted for five days, and the daily program contained many activities. Mathematics camps solved various codes and puzzles, programming camps made their own games etc. In addition to the actual learning tasks, all the camps contained different kinds of games and fun which also played a part in learning about the theme of the day.

The research was conducted mainly as a survey, but it also included some theme interviews. The open questions of the questionnaire were mainly analyzed by theoretical content analysis. Structured questions were addressed both in qualitative and quantitative terms. Spearman correlation coefficient was used to illustrate the correlations, as it is well suited to illustrating correlations of discrete variables that were present in this study. Theme interviews were transcribed, and also analyzed by theoretical content analysis.

Tables 1. and 2. present some examples of the theoretical content analysis in question number 7: What were the best things at the camp?

Table 1. Example of content analysis in question 7 (children)

\begin{tabular}{ll}
\hline Original answer & Classification \\
\hline I may have found a new friend & Friends \\
I learned new things & Learning \\
Going to a museum & Fieldtrips \\
To build a tall tower from marshmallows and spaghetti & Theme-related tasks \\
\hline
\end{tabular}

Table 2. Example of content analysis in question 7 (parents)

\begin{tabular}{ll}
\hline Original answer & Classification \\
\hline Trips & Fieldtrips \\
Miroscoping & Theme-related tasks \\
Doing experiments & Theme-related tasks \\
My son loved the experiments where he could build and design & Theme-related tasks \\
\hline
\end{tabular}




\subsection{Research reliability and validity}

In this study the internal validity of the research has been increased with triangulation of the methods. (Cohen et al., 2007) The material for this study was collected with both questionnaires in two years and with theme interviews. Research questions have been approached from different points of view when questionnaire and interview questions are drawn up to answer the question as fully as possible. Questions on the questionnaire have also been drafted by several people so that the researcher's personal views are not over-emphasized in the layout of the questions.

In order to be as reliable as possible to classify the sections derived from content analysis into the levels of relevance theory, reliability was studied through peer classification. In the peer classification, another researcher carried out the same classification on the basis of the relevance theory without seeing the original classifications. The peer classification is calculated by Cohen's kappa value, which describes the consensus among scientists.

The Cohen's kappa values obtained for the peer classification were separately calculated for classifications made for children and parents, although the ratings were very similar. The obtained kappa values were also almost the same with each other as expected: kappa(children) $=0.82$ and kappa(families) $=0.83$. Both kappa values ranged from 0.8 to 1.0 , which corresponds to very good compatibility between classifications (Landis \& Koch, 1977). The calculated kappa values therefore confirmed the reliability of classifications. 


\section{Results}

The following sections present the results of the research by research questions.

\subsection{Individual level of relevance was emphasized in the children's answers}

Table 3. presents the children's answers to question number 6: Why did you participate in the camp? Table 4. presents the children's answers to question number 7: Which were the best things at the camp?

Table 3. Why did the children participate in the camp - children's answers

\begin{tabular}{|c|c|c|c|c|c|}
\hline $\begin{array}{l}\text { Claim } \\
\text { I participated because... }\end{array}$ & $\begin{array}{l}\text { Relevance } \\
\text { dimensions }\end{array}$ & $\begin{array}{l}\text { Yes } \\
(\%)\end{array}$ & $\begin{array}{l}\text { Maybe } \\
(\%)\end{array}$ & $\begin{array}{l}\text { No } \\
(\%)\end{array}$ & $\begin{array}{l}\text { No } \\
\text { answer } \\
(\%)\end{array}$ \\
\hline & $\begin{array}{l}\text { Individual } \\
\text { Present }\end{array}$ & 69,1 & 22,0 & 4,4 & 4,5 \\
\hline \multirow[t]{2}{*}{ A. I'm interested in the theme } & Intrinsic & & & & \\
\hline & $\begin{array}{l}\text { Individual } \\
\text { Present }\end{array}$ & 28,5 & 41,7 & 25,2 & 4,6 \\
\hline \multirow[t]{2}{*}{ B. I wanted to make new friends } & Intrinsic & & & & \\
\hline & $\begin{array}{l}\text { Individual } \\
\text { Present }\end{array}$ & 55,8 & 29,0 & 10,6 & 4,6 \\
\hline \multirow[t]{2}{*}{ C. I wanted to learn more } & Intrinsic & & & & \\
\hline & Individual & 54,7 & 32,8 & 7,5 & 5,0 \\
\hline \multirow[t]{2}{*}{$\begin{array}{l}\text { D. I learned something that's useful in the } \\
\text { future }\end{array}$} & $\begin{array}{l}\text { Future } \\
\text { Extrinsic }\end{array}$ & & & & \\
\hline & Individual & 39,5 & 43,2 & 12,5 & 4,9 \\
\hline \multirow[t]{2}{*}{$\begin{array}{l}\text { E. I learned something that's useful in } \\
\text { school }\end{array}$} & $\begin{array}{l}\text { Present } \\
\text { Intrinsic }\end{array}$ & & & & \\
\hline & Vocational & 23,1 & 50,9 & 20,2 & 5,8 \\
\hline \multirow[t]{2}{*}{$\begin{array}{l}\text { F. I learned something that will help me } \\
\text { get the job I want }\end{array}$} & $\begin{array}{l}\text { Future } \\
\text { Extrinsic }\end{array}$ & & & & \\
\hline & $\begin{array}{l}\text { Societal } \\
\text { Present }\end{array}$ & 41,1 & 36,7 & 16,1 & 6,1 \\
\hline \multirow[t]{2}{*}{ G. I learned to cooperate } & Extrinsic & & & & \\
\hline & $\begin{array}{l}\text { Individual } \\
\text { Present }\end{array}$ & 53,9 & 30,4 & 10,8 & 4,9 \\
\hline \multirow[t]{2}{*}{ H. My parents wanted me to } & Extrinsic & & & & \\
\hline & $\begin{array}{l}\text { Vocational } \\
\text { Future }\end{array}$ & 47,3 & 41,7 & 6,0 & 5,1 \\
\hline I. My parents thought it would be useful & Extrinsic & & & & \\
\hline
\end{tabular}



Societal
$41,7 \quad 42,3$
$11,1 \quad 5,0$
J. I want to make a difference in the well-
Future
Intrinsic
Societal
$35,4 \quad 43,7$
$15,8 \quad 5,2$
K. I want to learn how to take care of the
Future
world
Intrinsic
Vocational
$25,6 \quad 54,36$
$14,7 \quad 5,3$
Future
L. I want to work in this field in the future
Intrinsic

Table 4. The best things at the camp - children's answers

\begin{tabular}{llll}
\hline Classification & Answer & Relevance level & Number of answers \\
\hline Activities & Theme-related tasks & Individual & 756 \\
& Playing (outdoors) & Individual & 191 \\
& Free time & Individual & 152 \\
& Fieldtrips & Individual & 138 \\
& Learning & Vocational & 89 \\
& Experimenting & Individual & 45 \\
Drawing & Individual & 21 \\
Hand-on activities & Individual & 20 \\
Problem solving & Vocational & 6 \\
& Competitions & Societal & 4 \\
& Friends & Individual & 128 \\
& Group work & Societal & 16 \\
Instructors & Societal & 61 \\
Getting help & Societal & 3 \\
Rules & Societal & 2 \\
Camp theme & Individual & 86 \\
Food & Individual & 61 \\
Everything & Individual & 57 \\
Laboratory & Vocational & 30 \\
Getting to know the building & Vocational & 8 \\
Videos & Individual & 6 \\
I don't know & Individual & 6 \\
The end of the camp & Individual & 5 \\
& Nothing & Individual & 2 \\
\hline
\end{tabular}


More than 91 percent of the campers thought that individual interest in the subject was, or at least perhaps, the reason for participating in the science camp. In addition to interest, the desire to learn more about the camp was highlighted in the answers. Almost 85 percent of campers responded as a reason, or as a possible cause, to participate in the camp with the desire to learn new. Both of these alternatives are represented in the relevance model by Stuckey et al. (2013) as the individual, present and intrinsic level of relevance.

The vocational level of relevance was the least emphasized of all the three levels of relevance. Only a little over 23 percent of respondents felt certain that they had learned something in the camp that would help them get to the job they wanted in the future. On the other hand, over $50 \%$ of respondents thought that they might have learned something in the camp that would help them get to the job they wanted. The answer to this and possibly the gap between the answers is most likely to be the fact that most of the campers were so young that they probably have no idea what they want to do in the future.

The most support of the dimensions at the societal level got the desire to influence the future of the planet and people's well-being in the future. More than $41 \%$ of the children chose this as one of the reasons for participating in the camp and over $42 \%$ felt that this was perhaps one of the reasons for participating in the camp. According to Stuckey et al. (2013), this alternative is in the societal, future and intrinsic level of relevance.

Questionnaire question 7 was an open question asking campers to find the nicest and most unpleasant things in the camp. The level of individual relevance was most pronounced in the nice things -answers, for example in the form of new friends and tasks in the camp. There was some societal and vocational relevance in the responses. "Learned something new" appeared in the responses 89 times. It was considered to present a vocational level of relevance.

To illustrate the correlation between the different dimensions of the relevance theory, the Spearman correlation coefficients between dimensions of different relevance were calculated with the SPSS program. The correlation coefficients were clearly greater than zero, most in the range of 0.0 to 0.5 , and correlations were significant mostly at $1 \%$ and $5 \%$ at significance levels. There was therefore a weak positive correlation between the different dimensions of the relevance, which means in this case that the campers who chose a particular option to assert their choice were 
quite likely to choose the same option for another claim. From the point of view of relevance, this can be interpreted so that those campers who considered the camps as relevant on one level considered them relevant at other levels as well.

In the theme interviews with families, the same questions were asked from both parents and campers themselves. The questions represented equally all levels of relevance. Interviews showed that the campers experienced the participation of the camp as relevant at all levels. The campers did not feel that the camps in any case had any negative impact on any level of relevance. In particular, the level of vocational relevance seemed to be emphasized in campers' responses.

\subsection{Impact of previous interest towards natural sciences to the relevance of science camps}

Interest, in this case, means either an earlier interest in chemistry or an interest in science, mathematics or information technology in general. In this section, the research material was limited to the data obtained from chemistry camps (109 responses), so relevance in this case is the relevance of participating in the chemistry camp.

Spearman's correlation coefficient for chemistry, and the relevance for chemistry camps was -0.288, and correlation was significant at $1 \%$ significance level. From this it can be concluded that relevance has a weak negative correlation with respect to the campers' interest in chemistry before participating in the camp. Children who have previously been interested in chemistry consider the camp less relevant than those who were less interested in chemistry before.

Spearman's correlation coefficient between general interest and chemistry camp relevance was -0.423 , and correlation was significant at $1 \%$ significance level. This means that the relevance still has a weak, but somewhat stronger, negative correlation with respect to the children's interest in chemistry before participating in the camp. It can therefore be concluded that campers who were interested in natural sciences have considered the camps even less relevant than those who were interested in only chemistry before the camp. 


\subsection{Impact of gender to the relevance of science camps}

Table 5. presents the answer percentages in boys' and girls' answers in question 6 .

Table 5. Differences in boys' and girls' answers

\begin{tabular}{|c|c|c|c|c|}
\hline Claim & Relevance dimensions & Answer & Boys (\%) & Girls (\%) \\
\hline \multirow[t]{4}{*}{$A$} & Individual & Yes & 65,0 & 62,1 \\
\hline & Present & Maybe & 23,8 & 34,5 \\
\hline & Intrinsic & No & 7,5 & 3,4 \\
\hline & & No answer & 3,8 & 0,0 \\
\hline \multirow[t]{4}{*}{ B } & Individual & Yes & 22,5 & 17,2 \\
\hline & Present & Maybe & 52,5 & 44,8 \\
\hline & Intrinsic & No & 22,5 & 34,5 \\
\hline & & No answer & 2,5 & 3,4 \\
\hline \multirow[t]{4}{*}{$\mathrm{C}$} & Individual & Yes & 50,0 & 51,7 \\
\hline & Present & Maybe & 40,0 & 34,5 \\
\hline & Intrinsic & No & 7,5 & 13,8 \\
\hline & & No answer & 2,5 & 0,0 \\
\hline \multirow[t]{4}{*}{$\mathrm{D}$} & Individual & Yes & 55,0 & 55,2 \\
\hline & Future & Maybe & 30,0 & 37,9 \\
\hline & Extrinsic & No & 11,3 & 6,9 \\
\hline & & No answer & 3,8 & 0,0 \\
\hline \multirow[t]{4}{*}{$\mathrm{E}$} & Individual & Yes & 51,3 & 51,7 \\
\hline & Present & Maybe & 28,8 & 41,4 \\
\hline & Intrinsic & No & 17,5 & 6,9 \\
\hline & & No answer & 2,5 & 0,0 \\
\hline \multirow[t]{4}{*}{$\mathrm{F}$} & Vocational & Yes & 17,5 & 17,2 \\
\hline & Future & Maybe & 55,0 & 65,5 \\
\hline & Extrinsic & No & 23,8 & 17,2 \\
\hline & & No answer & 3,8 & 0,0 \\
\hline \multirow[t]{4}{*}{ G } & Societal & Yes & 37,5 & 34,5 \\
\hline & Present & Maybe & 30,0 & 37,9 \\
\hline & Extrinsic & No & 28,8 & 24,1 \\
\hline & & No answer & 3,8 & 3,4 \\
\hline \multirow[t]{4}{*}{$\mathrm{H}$} & Individual & Yes & 65,0 & 48,3 \\
\hline & Present & Maybe & 22,5 & 41,4 \\
\hline & Extrinsic & No & 10,0 & 10,3 \\
\hline & & No answer & 2,5 & 0,0 \\
\hline \multirow[t]{3}{*}{1} & Vocational & Yes & 42,5 & 41,4 \\
\hline & Future & Maybe & 50,0 & 44,8 \\
\hline & Extrinsic & No & 5,0 & 13,8 \\
\hline
\end{tabular}




\begin{tabular}{cllll} 
& & No answer & 2,5 & 0,0 \\
& Societal & Yes & 37,5 & 48,3 \\
& Future & Maybe & 43,8 & 44,8 \\
& Intrinsic & No answer & 2,5 & 0,0 \\
& & Yes & 36,3 & 44,8 \\
K & Societal & Maybe & 42,5 & 51,7 \\
& Future & No & 18,8 & 3,4 \\
& Intrinsic & No answer & 2,5 & 0,0 \\
& & Yes & 22,5 & 27,6 \\
L & Maybe & 66,3 & 58,6 \\
& Vocational & No & 8,8 & 13,8 \\
& Future & No answer & 2,5 & 0,0 \\
\hline
\end{tabular}

Only chemistry-related camps were selected for this research question. The sample of this question was 109 respondents in total, of which boys 80 and girls 29 .

Responses to individual relevance related claims were fairly similar regardless of gender, but in four of the six allegations, girls had chosen the maybe option more often than boys. With respect to individual relevance the effect of gender seems to be mainly related to the fact that boys are more confident about what is individually relevant to them, and what is not. However, statistically the differences are not particularly significant.

On the statements regarding societal relevance, there is a small difference between the genders. It can be concluded that boys are slightly more interested in present-day events, while girls pay attention to the future, even though the p-value of the claims was more than 0.05 , meaning the result is actually not statistically significant.

Also, in these claims regarding vocational relevance, as claimed by societal relevance, the gender distribution was statistically insignificant ( $p>0.05$ ). Most of the boys and girls have responded "maybe" to all the claims regarding vocational relevance, probably indicating that issues related to vocational relevance are still far in the future. 


\subsection{Individual relevance emphasized also in the parents' answers}

In the parents' answers, like the children, the individual level of relevance theory was emphasized. More than 80 percent of parents thought that their children participated in the camp, as the child themselves was interested in the theme of the camp/ camp theme. Interestingly, 79 percent of parents admitted that their children attended the camp, because the parents wanted it. These two statements illustrate the individual level of the relevance theory, but the difference is that the former represents intrinsic relevance, while the latter is extrinsic.

The parents of the children, who participated in the camp, were asked in the questionnaire, which in their opinion were the three best things in the camp and which were the three worst things. The question did not really specify whether parents should answer from their own or from their child's point of view. In the answers of the parents, the significance of friends representing the level of individual relevance was most emphasized. Many campers had, according to parents, gotten new friends in the camp, but many campers were also attending the camp with a friend who was already familiar to them. Overall, the answers were fairly in line with the children's equivalents, as the camp program and the theme-related tasks received praise from the parents. According to the theme interviews, parents felt that the levels of individual and vocational relevance were especially emphasized in the camps.

Table 6. presents the parents' answers to question number 6: Why did your child participate in the camp? Table 7. presents the parents' answers to question number 7: What were the best things at the camp? 
Table 6. Why did the children participate in the camp - parents' answers

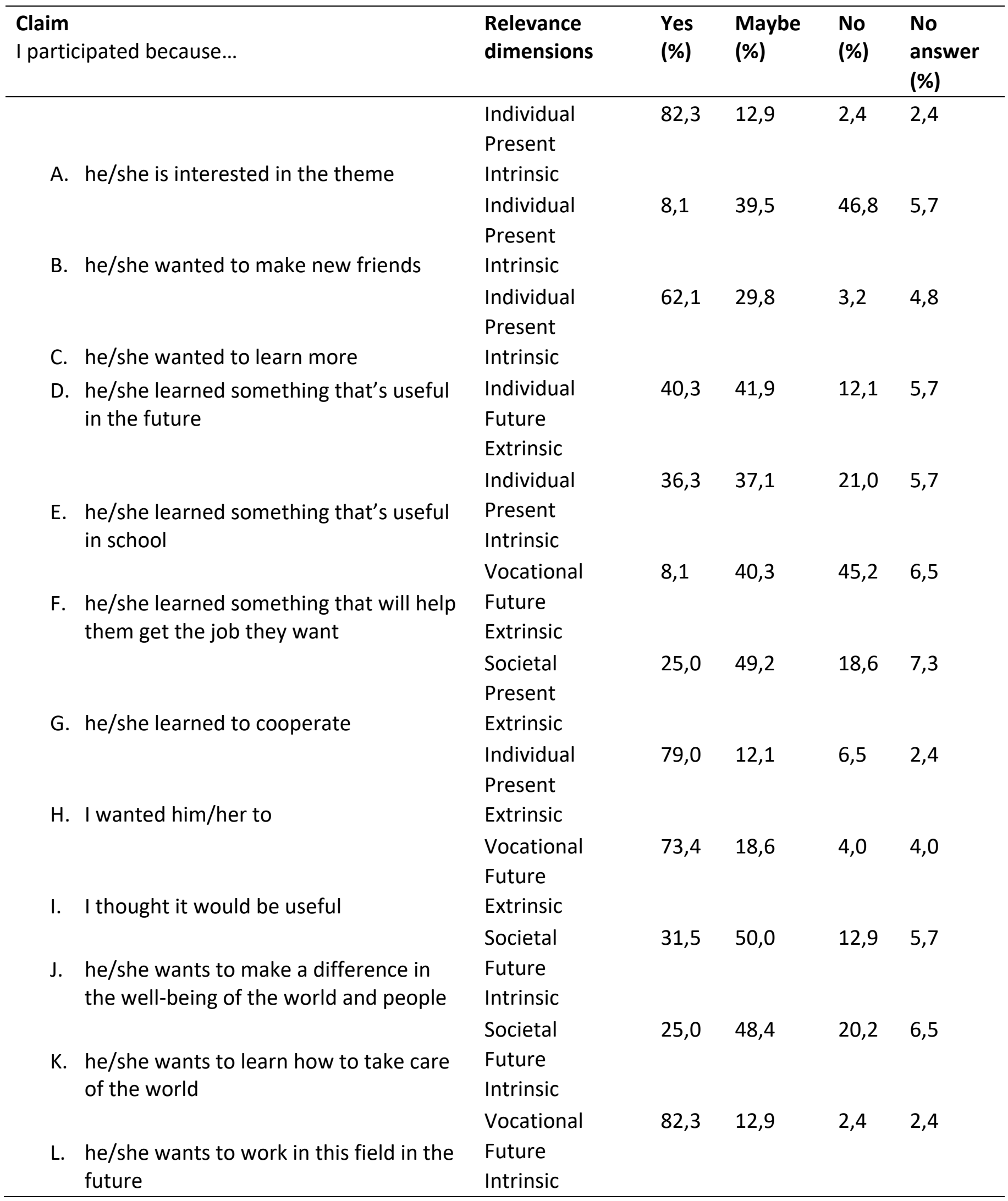


Table 7. The best things at the camp - parents' answers

\begin{tabular}{llll}
\hline Classification & Answer & Relevance level & Number of answers \\
\hline Activities & Program & Individual & 42 \\
& Experimenting & Individual & 25 \\
& Going outdoors & Individual & 14 \\
& Playing & Individual & 8 \\
& Fieldtrips & Individual & 7 \\
Social & Contents & Individual & 1 \\
& Friends & Individual & 44 \\
Other & Instructors & Societal & 26 \\
& Foorning & Vocational & 16 \\
& Interesting subject & Individual & 14 \\
& Interesting environment & Individual & 12 \\
& Location & Individual & 8 \\
& Courage to get interested in natural sciences & Vocational & 4 \\
& Challenges & Individual & 4 \\
& I don't know & Individual & 2 \\
& The feeling of success & Individual & 1
\end{tabular}

\subsection{Children's and parents' thoughts about the relevance of science camps are similar}

Parents' and children's answers were quite similar, with a few exceptions. According to the respondents, the campers have experienced a little bit more than their parents that they learned skills in the camps that benefit them in school, but the result is not statistically significant on the basis of the t-test, as p>0.05. Parents, on the other hand, have more often felt that their children have been involved in the camp because they (the parents) wanted them to. For this statement was calculated $p<0.001$, so the result was also statistically very significant.

The campers considered the camps more societally relevant than their parents. In every claim regarding societal relevance, campers have chosen the yes option more often than their parents, while the parents have opted for the option "no" more often than campers. Regarding vocational relevance, the children considered the camps to be a little more vocationally relevant than their parents.

Based on the theme interviews, the views of parents and their children on the relevance of science camps were very similar. In some of the interviews, the parents 
seemed to think that they had to guess about the views of their children, but after the child's interview it became apparent that the views were very similar. In particular, the question of societal relevance in relation to the group work skills of the camp seemed to be very challenging for many parents, and most of the time, they also mentioned the issue as difficult. The campers did not consider the issue as difficult.

\section{Discussion}

This chapter presents the results in the light of previous research findings, as well as the importance of research and further research topics.

\subsection{The relevance of non-formal learning environments from the children's perspective}

Although science camps have been researched in the past both internationally and in Finland (e.g. Tolppanen \& Aksela, 2014; Mohr-Schroeder et al., 2014), camps specifically for children have not been studied through the relevance theory. The results obtained will open up a new perspective for research on science camps and their development.

Both the survey and the theme interviews revealed that the level of individual relevance was very strongly represented in science camps. This supports earlier research results obtained from science camp research, in which the children's interest towards science increased during a science camp (e.g. Davis \& Hardin, 2013; Hayden et al., 2011; Nugent et al., 2010), as interest is most often handled with the level of individual relevance. The results of this study thus support the premise that nonformal learning environments have a positive impact on the interest in natural sciences. Since the relevance theory considers not only the personal relevance, but also the other two levels of relevance, new dimensions of societal and vocational relevance are entirely new to the development of non-formal science education.

Studying societal relevance proved to be challenging as the issues seemed to be fairly strange for elementary school children. Theme interviews studied societal relevance through teamwork skills, but the results were not particularly illustrative, as all respondents felt that they already had very good teamwork skills before the camp. However, the outcome of theme interviews was positive for the sake of societal relevance, as opposed to the material collected by the questionnaire. Only a small fraction of children had responded positively to the questions related to the vocational 
relevance. However, theme interview made it clear that vocational relevance was at least to some extent detectable in the camp.

Non-formal science education is being studied in order to develop it more and more to support learners and the results of this study showed that at the levels of societal and vocational relevance the science camps still need to be developed.

\subsection{The relevance of non-formal learning environments from the parents' perspective}

The vast majority of parents, such as children, highlighted the level of individual relevance. On the other hand, societal and vocational relevance were both equally weak in parental responses. Such a division between the answers is very similar to the general idea that children participate to the camps mainly from personal interest.

Parents were also asked to tell about their own interest in science, and this could also be an excellent subject of research, even though it was excluded from the scope of this study. Parents' own interest in science may have something to do with how relevant they experience non-formal science education in their child's life. Parents' rolein non-formal science education is an interesting matter that could be considered a potential topic for further research. The importance of families to childhood education is high, according to previous studies (e.g. Solomon, 2003; J eynes, 2005), so it would be sensible to continue researching the role of parents in the future.

The views of children and their parents on the relevance of science education were really similar to each other. This is not surprising since previous studies (e.g. J eynes, 2005; Crowley \& Callanan, 1998) show that parents and their opinions play a great part in how their children are concerned with studying natural sciences.

\subsection{The importance of the research}

According to recent studies, the knowledge and motivation to learn science is decreasing (e.g. Braund \& Reiss, 2006). Non-formal learning environments have been shown to have a positive impact on pupils' interest and motivation for studying natural sciences, so it is expedient to explore and develop these learning environments even better. Studying is meaningful and motivating to the learner when it is relevant to the life of the learner, both on the individual, societal and vocational level. In order to develop relevant education that covers all levels of relevance, one must first find out what kind of things the learners consider relevant. This mapping has been done 
in this study.

This research has shown that current non-formal learning environments are effective at the level of individual relevance. On the other hand, the levels of societal and vocational relevance are either not sufficiently achieved in the science camps or, alternatively, the theory should be better developed to fit children. As such, a survey questionnaire formulated on the basis of the relevance theory was unlikely to be the best possible for the target group and it would be appropriate to test the form first with children in the future so that the form of the questions would be as easy as possible for children's own life.

The research has been carried out in almost every camp at the University of Helsinki Science Education Centre in two years, and in the coming years, the corresponding research on the development of non-formal education will be done. When designing renewed camps, we will look at the information obtained from this study on what types of camps have previously been missing. This way, camps are likely to be more motivating and interesting, and more and more children can be enthusiastic about learning natural sciences.

While this research focuses solely on the study of non-formal science camps, the results of the research are justifiably meaningful, at least in the case of science clubs, and even in the case of formal school education. The results cannot, as such, be directly transferred to formal teaching, but they can be applied. In an ideal situation all forms of education: formal, non-formal and informal, support each other so that the learner gets the best support for learning.

In this study, the children attending the camps have been researched as well as their families. In the future, it would also be interesting to research theimpact of these science camps on the camp instructors. In the case of science education at the University of Helsinki, the camp instructors are often future science teachers and it can be assumed that instructing a science camp has at least some kind of effect on their teacher identity. 


\section{References}

Affeldt, F., Tolppanen, S., Aksela, M., \&Eilks, I. (2017). The potential of the non-formal educational sector for supporting chemistry learning and sustainability education for all students- a joint perspective from two cases in Finland and Germany. Chemistry Education Research and Practice, 18(1), 13-25.

Aksela, M., Wu, X., \& Halonen, J . (2016). Relevancy of the Massive Open Online Course (MOOC) about Sustainable Energy for Adolescents. Education Sciences, 6(4), 40

Braund, M. \& Reiss, M. (2006). Towards a More Authentic Science Curriculum: The Contribution of Out-of-School Learning. International J ournal of Science Education, 28(12), 1373- 1388.

Childs, P. E. (2006). Relevance, relevance, relevance. Physical Sciences Magazine, p. 14.

Cohen, L., Manion, L. \& Morrison, K. (2007). Research methods in education. New York: Routledge.

Crowley, K., and Callanan, M. A. (1998). Identifying and supporting shared scientific reasoning in parent- child interactions. J ournal of Museum Education 23: 12- 17.

Davis, K. E. B., \& Hardin, S. E. (2013). Making STEM fun: How to organize a STEM camp. TEACHING Exceptional Children, 45(4), 60- 67.

De Haan, G. (2006). The BLK '21' programme in Germany: A 'Gestaltungskompetenz'- based model for education for sustainable development. Environmental Education Research, 12, 19- 32.

Dillon, J . (2009). On scientific literacy and curriculum reform. International J ournal of Environmental \& Science Education, 4, 201- 213.

Eilks I. \&Hofstein A. (eds.) (2015). Relevant chemistry education, Rotterdam: Sense.

Eshach H., (2007), Bridging in-school and out-of-school learning: formal, non-formal, and informal education, J. Sci. Educ. Technol., 16, 171- 190.

Gilbert, J . K. (2006). On the nature of 'context' in chemical education. International J ournal of Science Education, 28, 957-976.

Hayden, K., Ouyang, Y., Scinski, L., Olszewski, B., \& Bielefedlt, T. (2011). Increasing student interest and attitudes in STEM: Professional development and activities to engage and inspire learners. Contemporary Issues in Technology and Teacher Education, 11(1), 47- 69.

Hofstein, A., Eilks, I., \& Bybee, R. (2011). Societal issues and their importance for contemporary science education: A pedagogical justification and the state of the art in Israel, Germany and the USA. International J ournal of Science and Mathematics Education, 9, 1459- 1483.

Hofstein, A., \& Kesner, M. (2006). Industrial chemistry and school chemistry: Making chemistry studies more relevant. International J ournal of Science Education, 28, 1017- 1039.

Jarvis T. and Pell A., (2005), Factors influencing elementary school children's attitude toward science before, during and after a visit of the UK national space center, J . Res. Sci. Teach., 42, 53- 83.

J eynes, W. H. (2005). A meta-analysis of the relation of parental involvement to urban elementary school student academic achievement. Urban Education, 40(3), 237- 269.

Keller, J . M. (1983). Motivational design of instruction. In. C. M. Reigeluth (Ed.), Instructional design theories: An overview of their current status (pp. 386- 434). Hillsdale: Lawrence Erlbaum.

King, D. (2012). New perspectives on context-based chemistry education: Using a dialectical sociocultural approach to view teaching and learning. Studies in Science Education, 48, 5187.

Krapp, A., \&Prenzel, M. (2011). Research on interest in science: Theories, methods, and findings. International journal of science education, 33(1), 27- 50. 
Landis, J . \& Koch, G. (1977) The measurement of observer agreement for categorical data. Biometrics 33. 159- 174.

Lyons, T. (2006). Different countries, same science classes: Students' experiences of school science in their own words. International J ournal of Science Education, 28, 591- 613.

Mandler, D., Mamlok-Naaman, R., Blonder, R., Yayon, M., \&Hofstein, A. (2012). Highschool chemistry teaching through environmentally oriented curricula. Chemistry Education Research and Practice, 13, 80-92.

Mutanen, J . (2015). Kehittämistutkimus biologian olympiavalmennuksesta: relevanttia tiedekasvatusta biologiasta kiinnostuneille. Helsingin yliopisto. Pro Gradu - tutkielma.

Nadelson L. S. \& J ordan J . R., (2012), Student attitudes toward a recall of outside day: an environmental science field trip, J . Educ. Res., 105, 220- 231.

Newton, D. P. (1988). Relevance and science education. Educational Philosophy and Theory, 20, 7- 12.

Nugent, G., Barker, B., Grandgenett, N., \&Adamchuk, V. I. (2010). Impact of robotics and geospatial technology interventions on youth STEM learning and attitudes. J ournal of Research on Technology in Education, 42(4), 391- 408.

Orion, N and Hofstein, A. (1991), Theme asurement of student's attitude towards scientific field trips, Sci. Educ., 75(5), 513- 523.

Osborne, J ., Simon, S., \& Collins, S. (2003). Attitudes towards science: A review of the literature and its implications. International journal of science education, 25(9), 1049- 1079.

Ramsden, J . M. (1998). Mission impossible? Can anything be done about attitudes to science? International J ournal of Science Education, 20, 125- 137.

Simon, S., \&Amos, R. (2011). Decision making and use of evidence in a socio-scientific problem on air quality. In T.D. Sadler (Ed.), Socio-scientific issues in the classroom: Teaching, learning and research. Dordrecht: Springer.

Singh, M. (2012). UNESCO GUIDELINES for the Recognition, Validation and Accreditation of the Outcomes of Non-formal and Informal Learning. PLA Inside Out: An International J ournal on Theory, Research and Practice in Prior Learning Assessment, 1(2).

Solomon, J . (2003). Home-school learning of science: The culture of homes, pupils' difficult border crossing. J ournal of Research in Science Teaching 40(2): 219- 223.

Stuckey, M., Hofstein, A., Mamlok-Naaman, R., \& Eilks, I. (2013). The meaning of 'relevance' in science education and its implications for the science curriculum. Studies in Science Education, 49(1), 1- 34.

Tolppanen S. \&Aksela M., (2013), Important social and academic interactions in supporting gifted youth in nonformal education, LUMAT, 1, 279- 298.

Tolppanen, S., \&Aksela, M. (2014). The International Millennium Youth Camp as an Active Learning Ecosystem for Future Scientists. In: Niemi H., Multisilta J., Lipponen L., Vivitsou M. (Eds.) Finnish Innovations and Technologies in Schools (pp. 145- 153). Rotterdam: SensePublishers.

Van Aalsvoort, J . (2004). Activity theory as a tool to address the problem of chemistry's lack of relevance in secondary school chemistry education. International J ournal of Science Education, 26, 1635- 1651.

Werquin, P. (2007). Terms, concepts and models for analyzing the value of recognition programmes. Teoksessa: Report to RNFIL: Third Meeting of National Representatives and International Organisations, (s. 2- 3). 